\title{
BELAJAR DAN KOGNISI: APLIKASI UNTUK DIVERSE CLASSROOM PADA PELAJARAN SEJARAH
}

\author{
Cindy Asli Pravesti \\ Dosen Prodi Bimbingan dan Konseling Universitas PGRI Adi Buana Surabaya \\ email: cindyaslibks2a12439@gmail.com
}

\begin{abstract}
Abstrak
Pengetahuan mengenai teori perkembangan dan teori-teori tingkah laku tentang bagaimana kita memproses informasi. Pengolahan informasi sangat kompleks karena siswa memiliki preferensi individu dalam belajarnya. Teori pemrosesan informasi membantu rencana guru terhadap preferensi tersebut dengan menunjukkan cara pengajaran berbeda yang dapat menampung beragam cara dalam belajar.

Cara berpikir mencakup pengolahan informasi yang kompleks, seperti; berbagai jenis memori, pemecahan masalah, perhatian selektif, masukan sensorik, dan proses pengambilan keputusan yang terlibat dalam pemikiran. Pemikiran pada tingkat yang tinggi tersebut dibantu oleh kemampuan dalam diri untuk memonitor pemikiran diri sendiri dan mengatur strategi yang akan digunakan untuk belajar.

Dengan memonitor dan berpikir mengenai proses pemikiran sendiri disebut sebagai metakognisi. Kemampuan siswa dapat diperkuat jika mampu berpikir secara efektif dan strategis dengan memanfaatkan proses metakognitif.

Pengajaran yang efektif mencakup pertimbangan cara belajar disukai siswa dan penggunaan gaya dalam mengajar yang mengakomodasi gaya belajar siswa serta sesuai dengan materi pelajaran yang diajarkan. Keberhasilan paling efektif sebagai guru jika dapat menawarkan kesempatan untuk siswa mengekspresikan pengetahuan mereka dengan cara yang berbeda dan termasuk berbagai strategi pengajaran yang diinstruksikan.
\end{abstract}

Kata Kunci: Belajar dan Kognisi, Informasi, Diverse Classroom

\section{LATAR BELAKANG}

Ketika berbicara soal sejarah, maka yang terpikir dalam benak adalah betapa rumitnya dan sulitnya dalam mempelajararinya. Kadang sejarah juga dianggap hanyalah urusan sekelompok kecil orang saja, seperti sejarawan atau orang yang berminat tentang sejarah. Sejarah juga dianggap hanya suatu peristiwa masa lampau, yang hanya perlu dikenang. Pemikiaran itu sebenarnya akan meracuni setiap benak generasi dalam mempelajari sejarah, akibatnya sejarah kurang menarik untuk dikaji dan dipelajari.

Pemahaman sejarah banyak disalahartikan mengenai pentingnya 
sejarah, tidak terlepas bagaimana mempelajari sejarah itu sendiri. Belajar tentang sejarah, hanya dianggap sebagai tanggung jawab guru sejarah. Banyak orang yang kurang menyadari, bahwa sebenarnya pendidikan sejarah merupakan tanggung jawab semua pihak. Demikian juga banyak guru sejarah sendiri, yang kurang menyadari tentang peranan mereka dalam membina pelajaran sejarah. Akibatnya banyak siswa dalam memperoleh pengajaran sejarah kurang memadai.

Jika hal itu semua terjadi, maka masyarakat atau generasi muda akan memahami sejarah, hanya sebatas peristiwa penting yang terjadi masa lalu. Jika demikian maka sejarah sendiri akan kehilangan makna yang terkandung dalam peristiwa yang terjadi. Sebab hakikatnya setiap peristiwa yang terjadi pada masa lampau atau masa kini semuanya mengandung makna yang akan memberikan pemahaman bagi setiap manusia yang mempelajari terhadap peristiwa itu sendiri.

Pemberian pemahaman arti pentingnya masyarakat dalam mempelajari dan memahami sejarah, maka harus dilakukan sedini mungkin. Sebagai langkah awal, belajar sejarah bisa dilaksanakan di sekolah. Banyak pendidik dan ahli berpendapat bahwa sejarah harus diajarkan di sekolah. Tercantumnya sejarah dalam kurikulum sekolah dimaksudkan untuk membangun kepribadian dan sikap mental siswa. Demikian pula mempelajari sejarah akan membangkitkan keinsafan akan suatu demensi waktu yang amat fundamental dalam eksistensi manusia, sebab hakekatnya eksistensi merupakan suatu kontinuitas, yaitu suatu gerakan dan peralihan yang terjadi secara terus menerus dari yang lalu menuju ke depan.

Berkenaan dengan gambaran tersebut diatas, maka betapa rumitnya dalam menyusun serta membangun kesadaran setiap manusia (siswa) untuk sadar tentang arti pentingnya sejarah yang mengandung nilai-nilai edukasi dalam kehidupan. Kesulitan dalam membangun kesadaran manusia tentang arti pentingnya sejarah, perlu juga dibangun suatu fondasi yang kokoh dalam pembelajaran sejarah, agar sejarah tidak lagi kehilangan makna. Kesan tidak menarik dan membosankan dalam setiap pembelajaran sejarah, disebabkan kurangnya guru menggunakan strategi dan metode dalam mengajar sejarah. Mengajar sejarah tidak hanya bisa diajarkan dengan mendikte teks, karena sejarah 
mempunyai sifat-sifat yang khas. Untuk itu, mengajar sejarah diperlukan suatu keterampilan. Pengajaran sejarah merupakan suatu proses yang rumit dan memerlukan kemampuan profesional yang tinggi untuk mengajarkannya.

Salah satu strategi dan metode pembelajaran sejarah yang akan ditawarkan adalah dengan menggunakan pendekatan pengolahan informasi kognitif. Pandangan ini memperhatikan pada bagaimana masukan indra yang kemudian ditranformasikan, direduksi, diuraikan, disimpan, serta untuk diperoleh kembali dan digunakan. Secara garis besar pengajaran sejarah membutuhkan hal tersebut diatas.

\section{PEMBAHASAN}

Persoalan yang terkait dengan pembelajaran sejarah tersebut, maka beberapa teori dicoba untuk ditawarkan sebagai jalan pemecahan pada persoalan pembelajaran sejarah itu sendiri. Salah satunya adalah teori pembelajaran yang dikemukakan dalam buku Jordan \& Porath (2006). Belajar adalah suatu kegiatan para siswa/warga belajar dengan bimbingan seorang guru atau dengan usahanya sendiri melakukan proses untuk mengisi pikirannya dengan berbagai pengetahuan.
Mengenai

pengetahuan pemrosesan dalam belajar, maka perhatian harus mengacu pada prosesproses kognitif yang terjadi dalam diri seseorang. Hal ini perlu dilakukan karena pada intinya belajar merupakan suatu proses pemberian informasi kognitif yang terjadi pada diri seseorang serta pemusatan perhatian pada proses belajar, dalam hal ini adalah pada pengelolaan informasi kognitif.

Pengetahuan mengenai teori perkembangan dan teori-teori tingkah laku tentang bagaimana kita memproses informasi. Pengolahan informasi sangat kompleks karena siswa memiliki preferensi individu dalam belajarnya. Teori pemrosesan informasi membantu rencana guru terhadap preferensi tersebut dengan menunjukkan cara pengajaran berbeda yang dapat menampung beragam cara dalam belajar. Cara berpikir mencakup pengolahan informasi yang kompleks, seperti; berbagai jenis memori, pemecahan masalah, perhatian selektif, masukan sensorik, dan proses pengambilan keputusan yang terlibat dalam pemikiran. Pemikiran pada tingkat yang tinggi tersebut dibantu oleh kemampuan dalam diri untuk memonitor pemikiran diri sendiri dan mengatur strategi yang akan 
digunakan untuk belajar. Memonitor dan berpikir mengenai proses pemikiran sendiri disebut sebagai metakognisi. Kemampuan siswa dapat diperkuat jika mampu berpikir secara efektif dan strategis dengan memanfaatkan proses metakognitif.

Pada tahun 1972, Newell dan Simon memperkenalkan model informasi pengolahan kognisi dan pembelajaran. Itu adalah sebuah garis deskriptif dari proses kognitif manusia, Hal tersebut abstrak direpresentasikan dalam proses seleksi dari pengetahuan, akuisisi, dan pemanfaatan, seperti yang dikemukakan oleh (Resnick, 1976 dalam Jordan \& Porath, 2006) bahwa analisis pengolahan informasi yang jelas dibedakan dari para behavioris melalui upaya eksplisit mereka untuk menggambarkan pengelolaan internal. Lebih lanjut dikemukakan bahwa mereka berbeda dari Gestalt yang kognitivifis dan Piaget dalam posisi mengupayakan mereka untuk menggambarkan alur aktual dari kinerja untuk menerjemahkan "restrukturisasi" atau "operasi logika" dalam urutan tindakan terorganisir secara temporal.

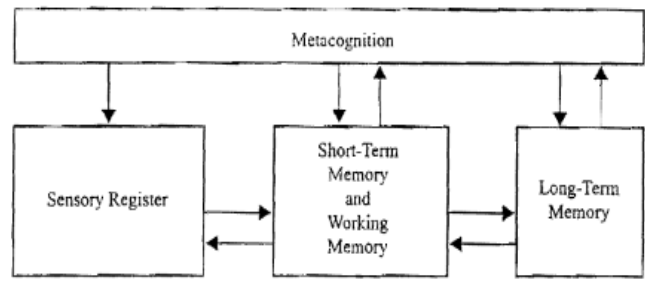

Gambar 1. Model Pemrosesan Informasi

\section{Aplikasi Pengolahan Informasi Kognitif dalam Pembelajaran Sejarah}

\section{Latihan berpikir kritis}

Proses latihan berfikir kritis ini, hendaknya siswa dihadapkan pada kesempatan untuk berlatih berfikir kritis dalam mengembangkan operasional formalnya. Dalam hal ini perlu dilaksanakan secara teratur. Pendekatan bisa dilakukan dengan pendekatan kegiatan induktif dan pendekatan berlawanan.

Pendekatan induktif ini diharapkan siswa untuk mampu membentuk konsep, menafsirkan data dan memikirkan berbagai aplikasi prinsip yang telah dibicarakan, siswa harus dihadapkan pada penggunaan konsep-konsep, prinsip dan prosedur untuk memecahkan masalah. Guru yang memberikan ceramah hendaknya juga bisa memberikan motivasi pada siswa. Guru berperan dan turut berpartisipasi dalam membantu siswa untuk menemukan 
konsep-konsep dengan memberikan kasus-kasus yang harus dicari jawabannya dangan cara merangsang siswa untuk bertanya atau kalau tidak siswa diajak untuk berdiskusi.

Guru mendorong siswa untuk membentuk konsep yang dapat dilakukan dengan menghadapkan siswa dengan berbagai permasalahan, pernyataan penting, dan suatu pokok persoalan. Berbagai ide bisa didaftar (brainstorming) dibahas dalam kelompok disusul dangan pertanyaanpertanyaan yang bisa dikemukankan oleh guru maupun oleh siswa sendiri. Hal terakhir ini bisa dilakukan dengan focus group discussion (FGD) yang melibatkan semua siswa. Siswa terdorong untuk menafsirkan data yang dapat dilakukan dengan berfikir kritis. Sehingga, siswa akan mampu untuk menggambarkan, menafsirkan, menyimpulkan apa yang telah mereka diskusikan. Mendorong siswa untuk mempraktekkan mengenai penerapan prinsip dapat dilakukan dengan mengikutsertakan siswa dalam membuat, menyusun hipotesis, menjelaskan gejala, menggunakan berbagai informasi atau memikirkan cara-cara untuk meluruskan pendapat siswa tentang implikasi dari berbagai konsep.

Dalam pendekatan kedua yaitu pendekatan berlawanan seorang guru merancang konten untuk menantang ide-ide siswa dengan menggunakan hal-hal yang berlawanan dengan pengalaman (experience) siswa. Siswa diminta melakukan penelitian terhadap apa yang menjadi ide atau menjadi temuan mereka baik yang dari dalam dirinya sendiri maupun dari orang lain (kasus).

\section{Latihan memecahkan masalah}

Guru yang melaksanakan pembelajaran melalui metode ceramah didepan kelas hendaknya mampu menggunakan berbagai keterampilan atau variasi yang dapat menimbulkan siswa untuk bertanya, atau guru dapat memulai dengan kasus yang nantinya merangsang siswa untuk bertanya. Kasus dapat menjadi sebuah tantangan dan menjadi faktor motivasi yang kuat bagi siswa untuk belajar. Siswa dapat didorong untuk memecahkan masalah dan untuk mengambil keputusan. Minat siswa dalam belajar akan tampak cukup besar dalam kegiatan ini. Guru hendaknya dapat mencari kasus yang dapat ditinjau dan relevan dengan kondisi yang ada.

\section{Penguatan}

Berdasarkan teori kognitif penguatan lebih menekankan pada penguatan dalam untuk memotivasi 
siswa, penguatan ini dapat berupa mengucapkan niat dalam hati, keteguhan hati dan sebagainya. Pembuatan rancangan instruksional siswa hendaknya diikutsertakan, sehingga kebutuhan siswa dapat terpenuhi. Disamping itu, penguatan dalam proses pembelajaran akan mempengaruhi cara berpikir pembelajar (siswa) dan akan memberikan kemampuan untuk membuat klasifikasi dan urutan yang ditentukan oleh pengetahuan dan topik yang kita miliki. Penguatan ini diharapkan untuk tidak menonjolkan masalah dalam pemberian nilai sehingga akan menurunkan motivasi mereka untuk mencari kajian belajar atau kajian dalam pemecahan masalah.

\section{KESIMPULAN}

Pengajaran yang efektif mencakup pertimbangan cara belajar disukai siswa dan penggunaan gaya dalam mengajar yang mengakomodasi gaya belajar siswa serta sesuai dengan materi pelajaran yang diajarkan. Keberhasilan paling efektif sebagai guru jika dapat menawarkan kesempatan untuk siswa mengekspresikan pengetahuan mereka dengan cara yang berbeda dan termasuk berbagai strategi pengajaran yang diinstruksikan.
Aplikasi teori belajar kognitivisme dalam pendidikan dan pembelajaran, yaitu guru harus memahami bahwa siswa bukan sebagai orang dewasa yang mudah dalam proses berpikirnya, anak usia pra sekolah dan awal sekolah dasar belajar menggunakan benda-benda kongkrit, keaktifan siswa sangat dipentingkan, guru menyusun materi dengan menggunakan pola atau logika tertentu dari sederhana ke kompleks, guru menciptakan pembelajaran yang bermakna, memperhatikan perbedaan individual siswa untuk mencapai keberhasilan siswa. Jadi dalam kegiatan pembelajaran guru lebih memusatkan perhatian siswa kepada cara berpikir atau proses mental anak, tidak sekedar kepada hasilnya.

\section{DAFTAR PUSTAKA}

Bransford, J. D., Brown, A. L. \& Cocking, R. R. 2000. How People Learn: Brain, Mind, Experience and School. Washington, DC: National Academv Press.

Donovan, M. S., Bransford, J. D. \& Pellegrino, J. W. (Eds.). 1999. How people Learn: Bridging Research and Practice. Washington, DC: National Academy Press. 
Jordan, E.A. \& Porath, M.J. 2006.

Educational Psychology: a Problem-Based Approach. Pearson Education, Inc.: USA. (Chapter 5; Learning and Cognition: Applications for Diverse Classroom).

McKeough, A. 1992. A NeoStructural Analysis of Children's Narrative and Its Development. In R. Case (Ed.). The Mind's Staircase: Exploring the Conceptual Underpinnings of Children's Thought and Knowledge (pp.171-188). Hillsdale, NJ: Erlbaum.

McKeough, A. \& Sanderson, A. 1996. Teaching Storytelling: A Microgenetic Analysis of Developing Narrative Competency. Journal of Narrative and Life History, 6, 157-192.

Newell, A. Shaw, J. C., \& Simon, H.

A. 1958. Elements of a Theory of Human Problem Solving. Psychological Review, 65 (3), 151-166.

Newell, A. Shaw, J. C., \& Simon, H. A. 1972. Human Problem Solving. Engle-Wood Cliffs. NJ: Prentice-Hall.

Sternberg, R. J. 1997. The Triarchic Theory of Intelligence. In D. P. Flanagan, J. L. Genshaft \& P. L. Harrison (Eds.), Contemporary Intellectual Assessment: Theories, Tests, and Issues (pp. 92-104). New York: Guilford.

Sternberg, R. J. 1998a. Ability Testing, Instruction, and Assessment of Achievement: Breaking Our of the vicious circle. National Association of Secondary School Principals Bulletin, 82 (595), 4-10.

Sternberg, R. J. 1998b. Principles of Teaching for Successful Intelligence. Educational Psychologist, 33, 65-72.

Sternberg, R. J. (Ed.) 1999a. The Nature of Cognition. Cambridge, MA: MIT Press.

Sternberg, R. J. 1999b. A Dialectical Basis for Understanding the Study of Cognition. In R. J. Sternberg (Ed.). The nature of cognition (pp. 51-78). Cambridge, MA: MIT Press.

Sternberg, R. J. (Ed.). 2000. Wisdom: Its nature, origins, and development. Cambridge: Cambridge University Press.

Sternberg, R. J. 2001. What is the common thread of creativity? Its dialectical relation to intelligence and wisdom. American Psychologist, 56, 360-362.

Sternberg, R. J. \& Dess, N. K. 2001. Creativity for the new millennium. American Psychologist, 56, 332. 
